\title{
Editorial: International Sustainable Ecological Engineering Design for Society (SEEDS) Conference 2018
}

\author{
Christopher Gorse ${ }^{1 *}$ and Lloyd Scott ${ }^{2}$ \\ ${ }^{1}$ School of the Built Environment and Engineering, Leeds Sustainability Institute, Leeds Beckett University, Leeds, \\ United Kingdom, ${ }^{2}$ Technological University of Dublin, School of Surveying and Construction Management, Dublin, Ireland
}

Keywords: smart cities, smart technologies, sustainable cities, sustainable communities, renewable energy, education and training, sustainable supply chain, COVID-19

\section{Editorial on the Research Topic}

International Sustainable Ecological Engineering Design for Society (SEEDS) Conference 2018

Climbing out of the pandemic there are calls for a more resilient and healthier economy. These demands resonating with a recovery plan based on smart integrated sustainable development that places the world on a trajectory to meet long-term climate and energy goals (IEA, 2020). A body of research is emerging capturing a need for a smart and sustainable existence and one which builds on the social, economic, and environmental needs. The research discussed here place emphasis on the social, training, education needs, and the technological and supply chain requirements for sustainable development. The work rightly presents a vision of development where built environments are sustainably reshaped with integrated energy solutions that are integral within the definition of a smart city. Ultimately, the proposition highlights some of the changes required to create urban environments that are more responsive to local needs, capitalizing on economic and technological development, without neglecting environmental and social costs.

In the wake of the pandemic the foresight of the Sustainable Development Goals are more pertinent. Our deliberations on smart sustainable development commenced at the 2018 Sustainability Ecology Engineering Design for Society conference which took place prior to the Covid 19 pandemic. At this point, in the brief history of humankind, meetings were still face-toface, with delegates traveling across international boundaries to discuss strategies for social and sustainable development. As a result of a previously unknown virus, for a short period, the way we would engage and address sustainability would change. As an immediate response international conferences and academic discussions went on-line and we adopted to new ways of living, some more sustainable than others.

In an attempt to reduce the rate of virus transmission and protect the public, the lockdown measures, restricted movement, and limited physical gatherings meant that global daily energy use drastically changed (Le Quéré et al., 2020; Liu et al., 2020). Emissions from personal travel and pollution in the major cities fell. However, as a consequent of home-based work the energy used in homes increased. And, with $<1 \%$ of homes benefitting from integrated renewable energy, domestic emissions rose.

The pandemic's restrictions increased the reliance on digital communication and media devices. Overnight we changed the way we worked, provided social care and engaged in home-based activity. Potentially new sustainable working practices were embraced, as a small but significant digital transformation took place and virtual meetings became the norm. While the need to offset the internet's increasing carbon footprint grew (Obringer et al., 2021), there was much to learn from the pandemic response. 
The devastating impact of Covid 19 changed mindsets and transformed homes into smart connected places for work, education, physical activity, and entertainment. The pandemic reinforced fragility of life, but it also demonstrated the human ability to respond to an existential threat. With the right motivation humankind can change the way we engage and live to reduce risks. The existential threat of climate change and the consequences are looming. Pollution, waste, and changing weather patterns are already affecting many, having a notable impact on the human health and mortality.

The need to ensure that homes and cities are sustainable has never been more pressing if we are to avert the consequences of climate change. A sustainable transformation, comparable to the pandemic response coupled with more extensive measures, is required to ensure a resilient ecosystem that allows humans to exist within in it.

Cities can be smart and healthier, with renewable and flexible energy systems integrated within them. The paper by Ibraheem et al. calls for integrated design solutions, where the building skin can provide both a smart protective envelope as well as a renewable energy generator. Such intelligent systems can help control the internal environment, improving comfort and reducing the demand placed on the building's heating and cooling system. The reduced building energy requirements can then be further offset by integrated photovoltaics. Using simulations and models the work demonstrates a need for integrated renewable energy, where passive solutions are unable to satisfy n-ZEB requirement. While renewable energy from the grid will be the dominant provider for the foreseeable future, clearly smart integrated facades can reduce demand and contribute to net zero solutions.

Simpson and Owen focused their attention on the need to create comfortable, affordable places to live, work, and exist in our communities. The research reviewed the capability and readiness of the supply chain to address the challenge of creating a more sustainable built environment. With the built environment responsible for $40 \%$ of global emissions, the work alerts us to the scale of the challenge posed by an aging building stock and the need to align and transform the supply chain. The stakeholders recognized the need for a more sustainable built environment and the social and economic benefits it brings. Key economic and social benefits including job creation, healthier places to live and work were prevalent in the discourse.

Weirs and Osborne contend that it is incumbent on educators to reinforce our understanding of climate change. The need to use innovative approaches to engage students, encouraged students to calculate their individual carbon footprint and to reflect on and calculate changes that they were able to make to reduce impact. With a better understanding of their personal actions

\section{REFERENCES}

IEA (2020). Sustainable Recovery. Paris: IEA. Available online at: https://www.iea. org/reports/sustainable-recovery (accessed February 2021).

Le Quéré, C., Jackson, R. B., Jones, M. W., Smith, A. J. P., Abernethy, S., Andrew, R. M., et al. (2020). Temporary reduction in daily global $\mathrm{CO}_{2}$ emissions during the COVID-19 forced confinement. and the carbon consequences personal experiences became a benchmark, aiding theory building and decision making at an industrial scale. Discussion centered around technology choices, material selection, and waste generated, as the students focused on strategies for reducing carbon emissions.

In response the competing definitions of what constitutes a smart and sustainable cities Toli and Murtagh posit that the main goal of technological driven definitions focus on improvements to the quality of life, yet all fail to address the social and environmental costs, while also downplaying economic sustainability. Whereas, the economic oriented definitions offer infrastructure and capital, creating competitive cities that boast benefits of sustainable economic development. Those definitions oriented toward sustainability capture combinations of human and social capital, against the capital invested in physical infrastructure, to deliver a sustainable and livable city. Surmising the competing positions a new definition is provided, a "Smart city is a concept of urban transformation that should aim to achieve a more environmentally sustainable city with a higher quality of life, that offers opportunities for economic growth for all of its citizens, but with respect to the particularities of each locality and its existing inhabitants" (Toli and Murtagh).

The themes presented in the papers connect to offer a position for a recovery from Covid 19 toward sustainable development, which remains both loyal to the human race and the health of the eco system which we rely on.

\section{AUTHOR CONTRIBUTIONS}

The authors Chaired the Sustainability Ecology Engineering Design for Society conference (SEEDS 2018) conference held at the Technological Institute Dublin, the 2019 SEEDS conference at the University of Suffolk and the subsequent on-line conference in 2020. During this period as the discussions commenced, CG and LS engaged and chaired the discussions, editing proceedings, and witnessing the changes in practice which the authors present and discuss above. The authors are indebted to the contributions made during these events and the lessons learned. CG and LS have contributed to this publication and the development of research within the SEEDS community. All authors contributed to the article and approved the submitted version.

\section{ACKNOWLEDGMENTS}

The authors would like to thank all of those contributing to the Sustainability Ecology Engineering Design for Society (SEEDS) conference that made this issue possible.

\footnotetext{
Nat. Clim. Change 10, 647-653. doi: 10.1038/s41558-020-0 797-x

Liu, Z., Ciais, P., Deng, Z., Lei, R., Davis, S. J., Feng, S., et al. (2020). Near-realtime monitoring of global $\mathrm{CO}_{2}$ emissions reveals the effects of the COVID-19 pandemic. Nat. Commun. 11:5172. doi: 10.1038/s41467-020-18922-7

Obringer, R., Rachunok, B., Maia-Silva, D., Arbabzadeh, M., Nateghi, R., and Madani, K. (2021). The overlooked
} 
environmental footprint of increasing internet use. Resour. Conserv. Recycling 167:105389. doi: 10.1016/j.resconrec.2020.1 05389

Conflict of Interest: The authors declare that the research was conducted in the absence of any commercial or financial relationships that could be construed as a potential conflict of interest.
Copyright (c) 2021 Gorse and Scott. This is an open-access article distributed under the terms of the Creative Commons Attribution License (CC BY). The use, distribution or reproduction in other forums is permitted, provided the original author(s) and the copyright owner(s) are credited and that the original publication in this journal is cited, in accordance with accepted academic practice. No use, distribution or reproduction is permitted which does not comply with these terms. 